\title{
Telemedicine services in the work of a doctor, dentist, nurse and midwife - analysis of legal regulations in Poland and the possibility of their implementation on the example of selected European countries
}

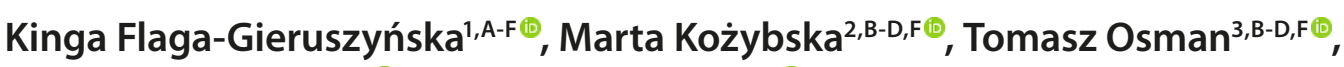 \\ Iwona Radlińska ${ }^{2, B-D, F \oplus}$, Paulina Zabielska ${ }^{3, D, F}{ }^{\oplus}$, Katarzyna Karakiewicz-Krawczyk ${ }^{4, D, F}$, \\ Anna Jurczak ${ }^{4, E-F} \oplus$, Beata Karakiewicz ${ }^{3, E-F} \odot$ \\ ${ }^{1}$ Department of Civil Procedure, Faculty of Law and Administration, University of Szczecin, Poland \\ ${ }^{2}$ Department of Medical Law of the Social Medicine Chair, Pomeranian Medical University in Szczecin, Szczecin, Poland \\ ${ }^{3}$ Department of Social Medicine and Public Health of the Social Medicine Chair, Pomeranian Medical University \\ in Szczecin, Szczecin, Poland \\ ${ }^{4}$ Department of Clinical Nursing, Pomeranian Medical University in Szczecin, Szczecin, Poland \\ A - Research concept and design, B - Collection and/or assembly of data, C - Data analysis and interpretation, \\ $D$ - Writing the article, E - Critical revision of the article, F- Final approval of article
}

Flaga-Gieruszyńska K, Kożybska M, Osman T, Radlińska I, Zabielska P, Karakiewicz-Krawczyk K, Jurczak A, Karakiewicz B. Telemedicine services in the work of a doctor, dentist, nurse and midwife - analysis of legal regulations in Poland and the possibility of their implementation on the example of selected European countries. Ann Agric Environ Med. 2020; 27(4): 680-688. doi: 10.26444/aaem/116587

\begin{abstract}
Introduction and objective. The aim of the study is to discuss the legal framework for telemedicine services in Poland, and to present telemedicine solutions used in selected European countries.

Materials and method. The analysis of legal cts was chosen as a research method in order to determine legal possibilities for medical professionals to use telemedicine services. A literature review was undertaken to demonstrate the possibilities of telemedicine as used in the United Kingdom, Germany, Norway, The Netherlands and Sweden.

Results. The Act on the professions of a doctor and a dentist states that the doctor and the dentist can perform their profession via ICT systems or communication systems. The doctor is obliged to practice in accordance with current medical knowledge and available methods. 'Available methods' include considering information and communication measures that may allow prevention, recognition or treatment. The Act on the profession of a nurse and a midwife states that the nurse and midwife perform the professions using current medical knowledge and the mediation of ICT systems or communication systems. Thus, the legislator has clearly authorized persons performing these professions to provide services in the field of telemedicine. However, despite the existence of a legal basis for using telemedicine, its development in Poland is not as high as in the United Kingdom, Germany, Norway, The Netherlands or Sweden.

Conclusions. The legislator gradually introduces legal solutions necessary for the development of telemedicine services, although the pace of these changes, as well as building the technical infrastructure that is the basis for the proper provision of telemedicine services, are too slow.
\end{abstract}

Key words:

telemedicine, medical law, distance medical activity

\section{INTRODUCTION}

Transformations in the forms and scope of the subject of health care services are a natural consequence of the development of medical sciences, and in the context of these considerations the growing opportunities in the field of IT and communication tools. In this way, new technical solutions appear, referring both directly to health care services and accompanying solutions related to the organization and management of these services. When analyzing the legal model for the provision of health care services in the scope of telemedicine in Poland, it is necessary

Address for correspondence: Marta Kożybska, Department of Medical Law of the Social Medicine Chair, Pomeranian Medical University in Szczecin, Poland

E-mail: marta.kozybska@pum.edu.pl

Received: 20.08.2019; accepted: 10.12.2019; first published: 28.01.2020 first of all to define the latter concept within the scope also adopted in this legal system. The most general definition of telemedicine indicates that it is a 'distance medical activity', indicating the key importance of medical education, regardless of the diagnosis and treatment process $[1,2]$. Another definition accepted in the Polish doctrine of medical law is the definition promoted by the American Telemedicine Association (ATA). According to this Association, telemedicine is 'the use of medical information exchanged from one site to another via electronic communications to improve a patient's clinical health status' [3]. These are only selected definitions present in Polish science and practice, and at the same time, the problem of delineating the telemedicine framework in the Polish legal system is all the more complex because not even a fragmentary, legal definition of this concept appears. 
First of all, an often misleading connection of the whole of telemedicine services with such concepts as 'e-medicine' or 'medical telecare' should be pointed out. The first case deals with a broader concept than telemedicine, covering also a broad aspect of medical education (e.g. online educational portals) and organizational and financial tools (e.g. systems for online patient registration, tools for statistical analysis). In contrast, medical telecare refers to one of the aspects of telemedicine, which is monitoring the health of the patient, in particular, the chronically ill who have difficulties with independent movement.

Consequently, for the purposes of this study it should be assumed that telemedicine can be discussed with reference to the use of means of distance communication in the doctor-patient and doctor-doctor relationships (for example, in relation to specialist consultations) at every stage of the patient's treatment process, starting with the diagnosis through the period of proper treatment, and ending on rehabilitation and monitoring the patient's condition beyond the completion of this process, including educational elements (in particular referring to a proper lifestyle, diet, exercises, and other pro-health behaviours) of an individual character (directed directly to the patient, his/her family and guardians), and not only presented in widely available or paid portals or applications. This delineation of the definition of the term 'telemedicine' allows for a precise reference to the legal framework for the provision of such services in the Polish legal system.

\section{OBJECTIVE}

The aim of this study was to discuss the legal framework for telemedicine services in Poland, pointing out the general assumptions of the admissibility of health care services within telemedicine, including its promotion and development. At the same time, the assumptions of providing services through ICT systems and means of distance communication by representatives of particular medical professions are analysed. The importance is also indicated of the role of the payer, whose policy of financing telemedicine services from public funds is of fundamental importance for their dissemination in the health care system.

\section{METHOD}

The analysis of legal Acts was chosen as a research method in order to determine the legal possibilities for medical professionals to use telemedicine services (Tab. 1).

In order to present the possibilities of telemedicine implemented in the United Kingdom, Germany, Norway, The Netherlands and Sweden, the literature has been reviewed. These countries were selected because they have made wide use of telemedicine for many years.

\section{RESULTS}

The possibility of using telemedicine by doctors and dentists. The regulations regarding the manner and scope of performing medical professions are of fundamental importance for the legal assessment of the admissibility of
Table 1. Legal Acts cited in the text

\begin{tabular}{ll}
\hline Name of the Act & Issues regulated in the Act \\
\hline $\begin{array}{l}\text { Act of } 5 \text { December } 1996 \text { on the professions of a } \\
\text { doctor and a dentist. Journal of Laws of 2017, item } \\
125,19 \text { January }\end{array}$ & $\begin{array}{l}\text { Rules for practicing the } \\
\text { profession of doctor and } \\
\text { dentist }\end{array}$ \\
\hline $\begin{array}{l}\text { Act of } 6 \text { November } 2008 \text { on Patients' Rights and } \\
\text { the Patient's Rights Ombudsman. Journal of Laws } \\
\text { of 2017, item 1318, } 4 \text { July }\end{array}$ & Patient's rights \\
\hline $\begin{array}{l}\text { Act of } 25 \text { June } 1999 \text { on cash benefits from social } \\
\text { insurance in case of illness and maternity. Journal } \\
\text { of Laws of 2017, item 1368, 12 July }\end{array}$ & $\begin{array}{l}\text { Rules for the allocation of } \\
\text { cash benefits in the event of } \\
\text { illness and maternity }\end{array}$ \\
\hline $\begin{array}{l}\text { Act of } 19 \text { August } 1994 \text { on Mental Health } \\
\text { Protection. Journal of Laws of 2017, item 882,5 }\end{array}$ & $\begin{array}{l}\text { Principles of caring for } \\
\text { people with mental } \\
\text { disorders }\end{array}$ \\
\hline $\begin{array}{l}\text { May } \\
\text { Health Care. Journal of Laws of 2017, item 1845, } 5\end{array}$ & $\begin{array}{l}\text { Principles of operation of } \\
\text { the information system } \\
\text { necessary to conduct State } \\
\text { health policy, }\end{array}$ \\
\hline $\begin{array}{l}\text { Act of } 15 \text { July 2011 on the professions of a nurse } \\
\text { and a midwife. Journal of Laws of 2016, item 1251, } \\
16 \text { August }\end{array}$ & $\begin{array}{l}\text { Principles of information } \\
\text { processing necessary to } \\
\text { conduct State health policy, }\end{array}$ \\
\hline
\end{tabular}

telemedicine services in the Polish legal system. For this reason it is worth referring first to regulations related to the standards of performing the professions of a doctor and a dentist. According to Art. 2 paragraph 1 of the Act on the professions of a doctor and a dentist $[4,5,6]$, performing the doctor's profession involves providing health care services by a person who has the required qualifications, confirmed by relevant documents, in particular: examining the state of health, recognizing and preventing disease, treating and rehabilitating patients, providing medical advice, and also issuing opinions and medical certificates. On the other hand, performing the profession of a dentist involves providing by a person who has the required qualifications, confirmed by relevant documents, the services specified in paragraph 1 , in the field of diseases of the teeth, mouth, facial part of the skull and adjacent areas $[7,8]$.

The above activities may also be carried out via ICT systems or communication systems (Art. 2, paragraph 4 of the Act). The latter standard was aimed at introducing into the legal order solutions facilitating the practice of the professions of a doctor and a dentist in the telemedicine model. This model is based on the provision of medical and health care services by combining elements of telecommunications, IT and medicine [9]. This solution is the first step in the implementation into practice the currently available services of telemedicine, which are important for the construction of modern standards of a doctor and a dentist.

While referring to the possibility of implementing telemedicine in accordance with the standards of practicing the profession of a doctor and a dentist, it is important to remember the axiological and ethical aspects, which play a decisive role in the interpretation of the provisions of Art. 4 of the Act on the professions of a doctor and a dentist. According to this provision, the doctor is required to perform the profession in accordance with current medical knowledge, available methods and means of prevention, diagnosis and treatment of diseases, in accordance with the principles of professional ethics and due diligence[10]. Undoubtedly, this provision refers to both substantive problems as well as technical and organizational aspects of the profession. Consequently, when talking about 'available 
means and methods', it is also necessary to consider IT and communication means that may allow for prevention, recognition or treatment. A classic case of this type is when the doctor, being aware of his or her limited knowledge about a particular condition, asks a specialist to consult the case by means of distance communication. Failure to do so in such circumstances will constitute a violation of the basic legal and ethical duties of the doctor, against the obligation of acting with due diligence.

The consequence of the above-mentioned general definitions and standards concerning the performance of both discussed professions are the provisions of Art. 42, paragraph 1 of the Act on the professions of a doctor and a dentist, which states that the doctor decides on the health of a particular person after examining him or her in person, or through ICT systems or communication systems. Examination in a remote form may include not only contact with the examined person using ICT systems and conducting an interview, but also allows becoming acquainted with the medical documentation provided in this way in order to give an opinion on the health of the examined person. However, if a test is carried out via an ICT system or communication system, it is not permissible to issue a medical certificate describing the personal appearance of the examined person as having been certified, as this constitutes a false statement of the lawful legal circumstances [11]. The person assessing the content of the medical certificate must have full information about all the circumstances of the conducted examination which formed the basis for its issuance, in particular the way in which the doctor contacted the subject. The certificate on the state of health is a substantive assessment of the health status of the examined person, regardless of the form of this assessment. This category includes both written health certificates as well as decisions regarding the health of a given person in a different form (e.g. placed in an ICT system). As a consequence, in all cases of deciding on the state of health, the solutions specific to telemedicine can be used, unless a special provision provides otherwise.

As emphasized in the literature [7], the discussed provision of Art. 42, paragraph 1 of the Act on the professions of a doctor and a dentist refers to the examination of a specific person, not a patient. Therefore, this provision may apply to the situations where the decisions concern persons other than patients within the meaning of the definition of a patient included in Art. 3, paragraph 1, point 4 of the Act on Patient's Rights and the Patient's Rights Ombudsman [12], according to which a patient is a person who applies for health care services or uses health care services provided by an entity providing health care services or a person performing a medical profession. This also applies to situations such as verifying the health of a witness in court proceedings by a forensic doctor, or other cases in which the doctor conducting the examination does not take part in the treatment process of the person being examined. In accordance with the judgment of the Constitutional Court [13], suspects and defendants alleged to have committed a crime and forced to undergo examination, for example, compulsory withdrawal of a blood sample in order to obtain evidence in criminal proceedings, pursuant to Art. 74 of the Code of Penal Proceedings, cannot be treated as patients. However, this interpretation is criticized by a doctrine as unjustified deprivation of patient status, when a person meets the definition of patient included in Art. 3 paragraph 1 point 4 [14].
As already indicated, the Polish legal system contains some special provisions which require the necessity of personal examination in the case of issuing medical exemptions (Art. 55 , paragraph 4 of the Act, on cash benefits from social insurance in the case of illness and maternity [15]), and before issuing a certificate or a referral for a person with mental disorders (Art. 11 of the Act on Mental Health Protection $[7,16]$. These exclusions seem justified due to the specifics of these examinations, requiring the doctor's personal contact with the patient.

Supplement to the general regulations relating to the admissibility of telemedicine in the Polish legal system are the provisions of the Act on the Information System in Health Care [17], which in Art. 36, paragraph 1, point 4 states that the minister competent for health care matters creates an education and information portal, the purpose of which telemedicine is also to disseminate knowledge on the functioning of information systems in health care and telemedicine. The provisions of the Act on Information System in Health Care apply to entities obliged to process data in the scope of health care, in particular to the minister competent for health care matters, local governor, the National Health Fund, Supreme Medical Council, Supreme Council of Nurses and Midwives, provincial pharmaceutical inspector, regional pharmaceutical chambers, Supreme Pharmaceutical Council, National Council of Laboratory Diagnostics, and Medical Centre for Postgraduate Education, as well as public and non-public health care facilities.

These provisions also apply to entities authorized to access data covered by the information system, and therefore to persons performing control activities of the information system and databases, to patients, their statutory representatives and persons authorized by patients, entities providing health care services to the extent necessary to ensure continuity of services, public authorities, national and provincial consultants and self-government bodies of medical professions in the scope necessary for the performance of their duties, in particular supervisory and control tasks [18]. Consequently, it should be assumed that one of the tasks of public administration bodies operating in the area of health protection and other entities performing public tasks, is to propagate the idea of telemedicine, which is undoubtedly connected with the obligation to implement such solutions in practice.

A different approach, which reduces the actions of public authorities only to the promotional sphere, would be a denial of the idea of a consistent legislator. For this reason, one cannot agree with the position of the provincial administrative court in Kraków, which stated that telemedicine services provided via the Internet are in fact providing advice, lectures, guidance on how to perform the exercises, their evaluation and monitoring, and consultations on health education. The court incorrectly stated that these actions could not be considered as medical care. At the same time, the court noticed that the medical care service requires at least a reliable determination if it is necessary to achieve the intended purpose, which results even from the rules of experience. According to this court, it is therefore necessary to be able to assess a patient's state of health in order to make a correct diagnosis, and to coordinate appropriate therapeutic treatment tailored to the requirements of the individual. It was emphasized that services based on information received from customers will not always be based on reliable, specific 
data that enable proper medical care. In this judgment, it was pointed out that the fixation of correct behavioural patterns cannot be equated with medical care [19].

However - as emphasized in the introduction of this study - telemedicine cannot be limited to information and promotion functions, also reflecting in shaping correct health attitudes (regarding diet, physical activity, etc.) or to providing medical care in remote forms. Each of these approaches should be considered as too one-sided in the face of such broad technical possibilities created by telemedicine. Furthermore, the legislator should create a legal framework that will take into account the flexible form of telemedicine services in health care.

Telemedicine services in the work of nurses and midwives. The professions of a nurse and a midwife, together the profession of a doctor, play a fundamental role in the treatment process. According to Art. 4, paragraph 1 of the Act on the profession of a nurse and a midwife [20], the practice of the profession of a nurse consists in providing health care services, in particular:

1) recognizing the conditions and health needs of the patient;

2) recognizing the patient's care problems;

3) planning and exercising care for the patient;

4) providing independently preventive, diagnostic, therapeutic and rehabilitation service, as well as medical rescue operations in a limited scope;

5) executing medical orders in the process of diagnosis, treatment and rehabilitation;

6) deciding on the type and scope of care and nursing services; 7) providing health education and health promotion. However, in accordance with Art. 5, paragraph 1 of this Act, the practice of the midwife's profession consists in providing health care services, in particular:

a) diagnosing pregnancy, taking care of a woman in the course of a physiological pregnancy, and conducting within a specific range examinations necessary to monitor a physiological pregnancy;

b) conducting examinations necessary for early diagnosis of high-risk pregnancy;

c) leading physiological delivery and foetal monitoring with the use of medical equipment;

d) receiving natural deliveries, if necessary also with a crotch incision, and in urgent cases also delivery from the pelvic position;

e) undertaking the necessary actions in emergency situations until the doctor arrives, including manual extraction of the placenta and, if necessary, manual examination of the uterus;

f) taking care of the mother and the newborn and monitoring the course of the postnatal period;

g) examination and care of newborns and taking all necessary measures, if necessary, including immediate resuscitation;

h) executing medical orders in the process of diagnosis, treatment and rehabilitation;

i) providing independently preventive, diagnostic, therapeutic and rehabilitation services in a limited scope;

j) preventing women's diseases and obstetrical pathologies;

k) recognizing in a mother or the child symptoms of abnormalities that require referral to a doctor;
1) exercising obstetric-gynaecological care over a woman; $\mathrm{m})$ conducting educational and health activities.

However, from the perspective of these considerations, the most important are the provisions of Art. 11 of the Act on the profession of a nurse and a midwife, which state that the nurse and midwife perform the profession with due diligence, in accordance with the principles of professional ethics, respect for the patient's rights, care for his or her safety, using current medical knowledge and the mediation of ICT systems or communication systems [21] Thus, the legislator has clearly authorized persons performing these professions to provide services in the field of telemedicine, which is a natural consequence of the nature of some nursing and midwifery services which do not require personal contact with the person involved.

The problem of data security in the Polish model of telemedicine services. Medical information is undoubtedly the foundation of communication between entities participating in networks and structures created within e-health. Information is present not only in personalized interactions between medical professionals and patients, and not only between professionals, but also in the circulation of documents within ICT systems, including those which have basic functions within telemedicine services (examination descriptions, diagnoses and other documents in the originally electronic or digitized form). It should be pointed out that the Polish legislator distinguishes documents which contain text, and those which constitute a sound or image records, but each one of them is a carrier of medical information and constitutes a component of the medical documentation collected during the provision of telemedicine services. The following data transmission models should be distinguished: 1) real-time - the patient and the entity performing the medical activity communicate 'live' (using especially in telepsychiatry, telecardiology, teleconsultations);

2) store and forward - digital data in the form of photos, video files, sound files are collected and stored on the patient's computer, mobile device or in the ether and transmitted via secured connection;

3) remote monitoring - the patient is monitored by means of a system that extracts data from monitoring devices and transmits them to the external headquarters, from where medical professionals oversee the patent's health condition (used in the case of chronic diseases, such as diabetes, asthma or heart disease) [22].

The protection of medical information in telemedicine in Poland faces many challenges and problems. First of all, there are technical problems related to the extant shortages in the field of broadband connections, and in those areas that have special needs in the field of telemedicine due to the distance of urban centres. Other problems are social issues related to digital exclusion and low level of competences in this area among elderly people and inhabitants of rural areas. In these circumstances, particularly difficult are the challenges arising from the currently applicable standards for the protection of personal data of a specific category (including information on health condition) resulting from the provisions of European Union law, in particular the Regulation (EU) 2016/679 of the European Parliament and of the Council of 27 April 2016 on the protection of natural persons with regard to 
the processing of personal dat, and on the free movement of such data, and repealing Directive 95/46/EC (General Data Protection Regulation, hereinafter referred to as GDPR), which has been in force since 25 May 2018.

There is no doubt that the entity that administers the application and other elements of telemedicine systems is in accordance with Polish regulations which are in accordance with the provisions of EU law, the administrator of personal data, obliged to use technical and organizational measures, ensuring protection of personal data processed, appropriate to threats and categories of data covered by this protection.

In the case of data transmission by means of teletransmission using the public network, it is always possible that the data might be retrieved by an unauthorized person. There is also the risk of unauthorized alteration, damage or destruction of data. The data administrator decides individually on its own on the typology of the security measures used. The recommended solution is the SSL data encryption protocol in the EV version (Certificates with extended validation). The SSL protocol uses standardized cryptographic algorithms, techniques and schemes to ensure security. SSL security certificates guarantee the correctness of the encrypted connection and confidentiality of data sent electronically. The certificate contains the necessary data that uniquely identifies the unit, and also allows determining whether the unit is the one which it claims to be.

At the same time, in the Polish legal system, a high level of security measures are applied which include primarily:

1) use of access control mechanisms;

2) protection against the operation of software, the purpose of which is to obtain unauthorized access to the ICT system;

3) protection against data loss caused by power failure or interference in the power supply network;

4) backup of data sets and programmes used for data processing;

5) application of means of protection against threats originating from the public network through the implementation of physical or logical safeguards to protect against unauthorized access;

6) monitoring of implemented means of protection in ICT systems.

These assumptions will undoubtedly be modified due to the entry into force of the GDPR, which will leave a strong mark on specific industry regulations introduced by the Polish legislator. Service providers in the Polish medical sector have taken measures to create an industry code of conduct in the field of personal data protection within the meaning of Art. 40 of GDPR. The grounds for the creation of this code include an unequivocal statement that it will contribute to the effective development of e-health in Poland, while maintaining appropriate and up-to-date standards of security and confidentiality of the data on the health condition of patients which are processed. The introduced security standards will not only provide some certainty for cross-border telemedicine service providers with respect to the collection, processing and storage of personal data, but it also addresses issues related to the processing of 'big data'.

New provisions around pseudonymisation and anonymisation of personal data are intended to instil trust and it is hoped this will help break down one of the barriers to the adoption of telemedicine services, while simultaneously providing a more harmonised regulatory framework for service providers [23]. These entities realize that the introduction of appropriate security systems is also important from the economic point of view. The cost of a breach of a patient's data security is estimated at 200 USD, while the cost of protection is just 8 USD per patient [24]. This is a new chapter in the development of telemedicine and standards of data protection of a specific category related to it.

\section{EXAMPLES OF THE USE OF TELEMEDICINE IN OTHER EUROPEAN COUNTRIES}

United Kingdom. The United Kingdom is one of the leaders in the effective implementation of telemedicine, not only in Europe, but also worldwide [25]. The British approach to telemedicine has a very pragmatic character. Initially, substantive research and implementation projects were initiated (in the 1990s alone, 216 of such projects were financed and implemented [26]), and if positive effects were noted, appropriate legislative documents enabling the implementation of good practices into reality were implemented. One of the first important documents, 'Information for Health' issued in 1998 by the Department of Health of England and Wales, included a recommendation that every health programme, health strategy, etc. implemented in force after, must contain solutions based on telemedicine, and all local health facilities must implement solutions enabling the provision of services based on telemedicine until 2005.

In the United Kingdom, of great importance were also legal Acts which did not refer directly to telemedicine, but constituted its foundations, i.e. the 'The UK Data Protection Act' (1998). This document regulated issues related to the protection and processing of personal data, which are of particular importance in the context of telemedicine, the essence of which consists in transmitting sensitive personal data concerning, e.g. the health status between different persons and institutions [27].

The United Kingdom has developed a model of operation in which one specific legal Act on the functioning and implementation of telemedicine has not been adopted. However, in the practice of the National Health Service (NHS) and the health programmes implemented by this institution, it is often a necessary and integral element. This state of affairs raises certain legal difficulties because although the NHS constantly provides telemedicine services to its patients, it has not been clarified exactly when and in which situations medical personnel are required to physically contact the patient, and when it is allowed to do so remotely via modern information and communication technologies (ICT). This affects the legal responsibility of the medical personnel for the medical advice provided to a patient using telemedicine; which is ambiguously defined and raises legal doubts [28].

Germany. The second largest telemedicine service market in Europe (just after the UK) is Germany. The development of this market would not have been possible without appropriate legal regulations stipulating the way in which telemedicine operates in Germany. The most important legal regulation is the law passed in December 2015 regarding e-Health. It clarifies issues such as data management, protection of personal data, information security, rules for participation of private entities in the telemedicine service market, and indicates sources of financing [29]. The method of access to 
medical data seems particularly interesting. The legislator indicated that the only person authorized to use the data and authorize other persons or entities is the patient himself, who for this purpose has an electronic Health Card. Access to medical data is possible only after the patient hands over the card and enters the PIN number.

On the other hand, the German code of conduct for doctors included in the document 'Professional Code for Physicians in Germany' specifies that: 'physicians may not perform individual medical treatment, in particular medical counselling, exclusively via print and communications media. It must also be ensured that that physicians treat patients directly in the case of telemedicine procedures' [30]. This provision indicates a relatively high distrust of decision makers and somewhat hampers the development of telemedicine in Germany. In each case of using telemedicine it requires carrying out direct meetings of a patient with a doctor, even if there are no medical premises.

This specific dualism in the approach to telemedicine results from the mentality of German society and the political decision-makers. On the one hand, Germans prefer individual contact with medical personnel, but on the other hand, limited human, financial and time resources do not always make this possible, leaving the only alternative solution based on telemedicine.

Norway. Norway is a country with a highly developed telemedicine market. This results, among others, from its specific geographic location, a large area per one inhabitant, where access to medical services is sometimes difficult (especially in Northern Norway) [31]. The above conditions resulted in the first pilot projects being implemented already in the 1980s. Together with their first positive effects, in 1993, the Department of Telemedicine at the Ministry of Social Affairs was established [32], followed in 1997 by the creation of the Norwegian Patient Register, the institution responsible for collecting data necessary for the effective implementation of telemedicine-based services [33]. However, the legal foundations for Norwegian telemedicine have been created only in recent years. Among others, the Norwegian Health Research Act (2008) and the Personal Data Act (2000) were adopted. Both documents were adopted in a spirit of trust and confidentiality: the medical personnel depend on the information provided by the patient, and the patient trusts that the information provided is treated confidentially. This assumption makes the developed legal solutions not as restrictive as in other European countries.

The fact of the responsibility of medical personnel for services provided with the use of telemedicine is also significant. The Norwegian Health Council states that health advice provided both on the basis of information provided by the patient in a traditional form (direct so the responsibility of medical personnel is therefore the same [27].

The Netherlands. In The Netherlands, telecare is implemented primarily in the public health system available to patients after hours, the so-called after-hours care, i.e. 17.00 - 8:00 on weekdays, and on weekends without any breaks from 17:00 on Friday 08.00 on Monday, in which nurses and family doctors employed in primary care cooperatives (PCC) participate, or if necessary implemented by the emergency department of hospital (ED).Throughout the country there are around 120 PCCs with 40 - 120 family physicians for a population of 50,000 - 500,000 [34]. The after-hours care model assumes cooperation between two systems of hospital EDs and PCCs. The system in its present form has been in operation for about 20 years and can be a model for others.

In order for a patient to get medical help during the afterhours care, the following procedures are available:

- call the telephone number indicated for a given PCC region - which is most encouraged option $(85 \%$ use the cooperative's telephone number [35]), where he/she will receive nurse telephone consultations;

- phone the national emergency number (112);

- visit the ED of hospital in region.

However, in some cooperatives, the initiation of help can take place through computer-based decision-support. The cooperative's telephone number is operated by trained nurses supervised by family doctors. The nurses conduct an interview, on the basis of which they decide what help should be provided to the patient. The nurses conduct teletherapy based on protocols and guidelines, supported by evidence, which they use during conversation with the patient, which can be continued in the form of:

- direct contact in the cooperative (about 35\%);

- house calls - which can result in a doctor's visit at home (about 15\%);

- referral to a hospital (about 6\%) [35].

Doctors who make house calls have the primary care cooperative car at their disposal, which is a car with trained chauffeurs, equipped with first aid devices, such as: communication equipment, oxygen, infusion drips, and automatic defibrillators. These calls concern very urgent or moderately urgent health problems, although $22 \%$ are provided for non-urgent problems. As much as $90 \%$ of house calls are for older people (age 65 or older) [35].

In a situation when a home visit is not possible or insufficient, it is the doctor who calls an ambulance from a hospital. A 2003 study shows that only about $21 \%$ of house calls ended with a referral to the hospital [35]. The primary care cooperative car can be used as a medical transport when the case is very urgent, the ambulance called by a doctor is unavailable, and the patient's condition allows it [1].

Another 2003 study shows that patients who received only telephone consultations from nurses were less satisfied than those who had direct or telephone contact with a family doctor [35]. Later studies (2005) from the Maastricht region in The Netherlands show a general satisfaction of patients within the entire system [36]. The introduction of telephone consultations from nurses before consultations with a doctor also resulted in increased job satisfaction of physicians, mainly by limiting their work hours (before the introduction of consultations from nurses -19 on-call hours of the doctor, after the introduction of consultations from nurses -4 hours) [37].

The study in the Maastricht region in the field of services shows a decrease in the demand for the following services:

- contacts with emergency care (reduction by $53 \%$ );

- ambulance calls (reduction by $12 \%$ );

- self-referrals to the ED (reduction by $89 \%$ );

- hospital admissions (reduction by $34 \%$ ).

However, contact with primary care has increased by about $20 \%[38]$. 
In the public care system, it is also possible to use certain elements of telecare during the office hours of emergency care. In a case of non-life threatening emergencies, it is recommended to contact the appropriate primary care cooperative (PCC) first - it is possible to receive telephone consultations from a nurse or a doctor. If necessary, the physician refers to the emergency department of a hospital (ED). In a life-threatening situation, it is recommended to dial 112 directly [39]. In both systems (in/after hours), consultations with a doctor or a nurse are included in the basic insurance costs (services provided under PCC); however, patients dependant on health insurance participate in the costs of assistance received in other areas (ambulance calls, self-referrals to the ED, hospital admissions).

Other forms of telemedicine (documentation in electronic form, using the Internet to access information) are used mainly by about $97 \%$ of general practitioners, although not to facilitate the physician-patient communication, but to use them in the interdisciplinary field (storing medical records, e-prescriptions). Telemedicine in The Netherlands is used to a very limited extent to improve the patient's competence for self-care and own health management. The low level of patient empowerment in telemedicine is regrettable.

Telemedicine in a more advanced level than telephone consultations, e.g. in the form of a telephone application or information portals, is used in The Netherlands to a limited extent in various areas of specialist services (self-control in treatment of diabetes, assistance with a conscious choice of appropriate health insurance); however, there is no good evaluation of the use of this type of telemedicine.

Large financial outlays on this type of telesystem have not resulted in spectacular profits, for example, in the form of raising health awareness or improving health condition. The lack of outlays for checking the results of this type of investment does not allow their adjustment to the actual needs of the patient. Patients, therefore, sporadically use applications that they do not understand, and that are not adequate to the needs or not sufficiently interactive (lack of recipients of critical remarks). As claimed by the advocates of the idea of patient empowerment, a good e-health application should provide three elements:

1) an appropriate level of patient information (patient is informed);

2) provide skills to solve problems and provide a sense of self-efficacy (patient is skilled);

3) motivation to manage patient's own health (patient is motivated) [40].

Sweden. Sweden is an example of a country that uses various forms of telemedicine in a variety of ways. In Sweden in the 1990s, attention was paid to telemedicine as a tool to meet growing health needs and reduce the cost of medical care [41]. It should be noted that there are various telemedicine projects operating in 21 administrative regions. Their autonomy makes it difficult to introduce coherent systems throughout the whole country [42].

One of the projects implemented in central Sweden was 'The Eye'. The purpose of this project, developed by ophthalmologists and general practitioners, was to enable the treatment of selected eye diseases at the level of primary health care, thanks to video transmission between the general practitioner and the ophthalmologist. In this case, telemedicine allowed reduction of the territorial distance between primary health care facilities and ophthalmic hospitals $[41,43]$.

'The Heart Project', started in 1997, was directed to patients with heart failure. It consisted in a video connection of primary health care facilities with cardiologists in a hospital. Teleconferences were held once every two weeks. During those meetings, the results of patient examinations were discussed. The aim of the project was not so much to reduce territorial differences as to speed up the diagnosis and, as a result, start treatment $[41,44]$. Spri warns that facilitation of contacts with specialists may lead to the over-use of specialists' services by family doctors. It notes that if the goal was to provide treatment for heart failure at the level of primary health care, primary health care physicians should be educated by joint discussion of cases. However, Spri raises the question whether a high level of cardiology competence should be required from a primary health care physician, and if the goal was to start treatment quickly, the priority should be to give primary health care doctors the possibility of quick contact with specialists. The argument against this solution is that it could be at the expense of other patients waiting for cardiac consultation $[41,44]$.

'The North' project is an example of the use of telemedicine to ensure the highest quality of services in rural areas. The project implemented a connection between a university hospital (specialists in the field of ENT, orthopaedics and dermatology) and two primary health care facilities. Consultations included video-conferencing and image exchange (X-ray images, and photographs of skin lesions, nose, throat and ear). The project is an example of equalizing inequities in health among the inhabitants of northern, mountainous, hard-to-reach rural areas $[41,45]$. 'The South' is an example of using telemedicine for organizational changes. The project created a joint electronic archive of radiological images for connected hospitals $[41,46]$.

Currently, telemedicine is becoming more and more popular in Sweden. Since 2016, primary health care doctors are available via video with the use of smart phones [42]. This shortens the time of waiting for a patient, reduces the risk of spreading infectious diseases, and reduces the problem of transport to a health facility [47]. However, it is noticed that the ease of obtaining a service can lead to an increase in the number and, at the same time, the cost of services [42]. Therefore, it is proposed to introduce a minimum fee for the use of 'digital services' in the amount of $\approx € 10$ [42]. In addition, telemedicine in Sweden is criticised for making medical diagnosis only on the basis of a video interview, a live consultation should also be required. Additionally, online doctors have a tendency to over-prescribe medication, especially antibiotics, and the ease of obtaining e-visits leads to the over-use of services $[42,48,49]$.

\section{DISCUSSION}

While discussing the considerations regarding the Polish legal model for the provision of telemedicine services, it should be emphasized that the process of adapting the Polish legal system to the development of this type of services is still under construction. The legislator is just beginning to notice legal and organizational problems related to telemedicine, which still cause, among others, deficiencies in the scope of regulations with respect to some medical professionals, despite the fact that by the nature of the services they provide, 
they are the basic target group of IT tools being created for the needs of telemedicine.

It is also worth remembering that the creation of a legal framework at the statutory level is only the first stage of the actual implementation of telemedicine solutions into the reality of the Polish health care system. Their actual implementation can take place only together with simultaneous introduction of the instruments of their financing by a public payer, which is the National Health Fund. The introduction of individual services of this type to refunded benefits is a half-way solution and has marginal importance for the development of telemedicine, considering that the foundation of the health care system in Poland are benefits financed from public funds. The unhurried operation of the payer in this case seems not only unjustified, but even harmful, because the telemedicine services surely affect positively the services provided, in particular their efficiency, e.g. significant shortening of the response time due to ongoing monitoring of the patient's condition, but also their cost-effectiveness, inter alia, the use of distance communication reduces the need for patient's personal contact with medical staff. This certainly meets the demand fortherational spending of public funds, while providing comparable and often higher quality of health care services. In this respect, the availability of telemedicine services is also important. In Polish reality, one cannot overlook the fact that in this way county health care entities also acquire the possibility of practically unlimited geographical specialist consultations, and patients living in remote areas with access to the Internet gain, in certain areas, the current assistance of medical professionals.

The introduction of telemedicine services on a wider scale may be necessary considering the needs of an aging population and the growing shortages of medical staff. The striving to improve the quality of life of patients, especially those chronically ill or disabled, is one of the determinants of the development of a modern health care system. For this reason, the demands of both providers and beneficiaries regarding the introduction of a bolder refund policy in relation to telemedicine by the National Health Fund, are correct. Perhaps this will allow for an extensive use of telemedicine in Poland as is used in other European countries.

Poland, as a country with rapidly aging society, is facing problems similar to those experienced by Germany, Great Britain, Sweden, etc. These countries treat telemedicine as an effective (in terms of time, organization, and finance) solution to problems with providing medical services, especially for elderly people who are their main consumers. Therefore, it is worth discussing which solutions applied in other countries can be beneficial in the Polish reality.

When considering the organizational and legal solutions that could be implemented in Poland, several aspects should be taken into account. The first is the role of the Polish public administration, whose prime mover is understood as the ability to make quick and right decisions appropriate to the needs, and then put them into practice, is rather limited. The second aspect is a private ICT sector with relevant specialists, which is developing in Poland very quickly, and which is indispensable to every efficiently-working telemedicine-based solution. Suffice to say that half of the Polish start-ups develop in the ICT sector, and that the turnover rate for this sector rises annually by $8.6 \%$, on average, which is the best result in the whole of Europe [50]. The last very important aspect is the fact that in Poland there are private and non-governmental sectors that are leaders in the implementation of innovative solutions in the field of telecare and telemedicine. These are sectors where the personnel have the necessary experience, knowledge, and skills.

Bearing in mind the above arguments, it seems that the most effective model of telemedicine implementation in Poland is the British model, where the role of the State is restricted to the creation of the legislative framework, provision of funds, and evaluation of the effectiveness of actions taken. Working-out specific solutions, putting them into practice and their further functioning, should be on the side of both the private and government sectors.

It seems unreasonable to follow the Scandinavian or German models, where the State plays a vital role in the development and functioning of telemedicine. In the case of Poland, it could spell a substantially lower effectiveness of telemedicine implementation, among other things, due to limited experience and competence in this field of the representatives of this sector.

Nevertheless, the above considerations are only conjectures and subject to debate. The formulation of concrete conclusions requires many pilot studies in the field of telemedicine and thorough analysis, as has been performed in the majority of countries where telemedicine is already an efficiently working element of the health care system.

One of technical solutions that seems particularly worth taking into consideration for implementing in Poland, is using remote healthcare outside working hours of primary healthcare centres, as implemented The Netherlands. This could significantly improve the functioning of hospital emergency departments, which could then focus on cases requiring immediate intervention. An interesting idea introduced in Sweden is that of remote medical consultations between primary healthcare and specialist centres.

\section{CONCLUSION}

The analysis of selected regulations related to the rules of performing the medical professions of a doctor, dentist, nurse and midwife showed that the legislator gradually introduces legal solutions necessary for the development of telemedicine services, although the pace of these changes, as well as building the technical infrastructure that is the basis for the proper provision of telemedicine services, are too slow, especially compared to countries like the United Kingdom, Germany, Norway, The Netherlands and Sweden.

Poland is an average-size European country with the area of $312,679 \mathrm{~km}^{2}$ - the $11^{\text {th }}$ largest country in Europe, and with a population of approximately 38 million people [51]. About 15.3 million residents of Poland live in rural areas, which very often contend with the problem of the availability of medical care, resulting from medical staff shortages and the concentration of health care centres in cities. Comparing this with the data on the availability of the Internet in Poland (84.2\% of households have access to the Internet) and the scale of using the possibilities it offers $(77.5 \%$ of Poles use the Internet, a number that shows an upward trend) [52], it can be said that the Internet has great potential to support the development of telemedicine services in Poland. The use of appropriate legislative, organizational, and technical solutions may reduce the problem of the availability of medical services, especially in rural areas. 


\section{REFERENCES}

1. Lops K. Cross-border telemedicine. Opportunities and barriers from an economical and legal perspective. Rotterdam: Erasmus University - Institute of Health Policy and Management; 2008.

2. Chojecka M, Nowak A. Telemedycyna na tle polskich regulacji prawnych - szansa czy zagrożenie? IKAR 2016; 8: 75-76.

3. American Telemedicine Association. ATA Wiki [Internet]. [cited 2017 Nov 30]. Available from: http://www.americantelemed.org/the-source/ ata-wiki.

4. Glanowski G. Telemedycyna w świetle ustawy o zawodach lekarza i lekarza dentysty, Monitor Prawniczy 2015; 18: 978.

5. Nowak A. Telemedycyna transgraniczna - problematyka prawa właściwego dla przypadków odpowiedzialności cywilnej podmiotów medycznych na gruncie prawodawstwa unijnego. PME 2018; 1: 37.

6. Act of 5 December 1996 on the professions of a doctor and a dentist. Journal of Laws of 2017, item 125, 19 January (consolidated text: Journal of Laws of 2019, item 537, PL: t.j.Dz.U. 2019, poz. 537).

7. Kopeć M (editor). Ustawa o zawodach lekarza i lekarza dentysty. Komentarz. Warsaw: Wolters Kluwer Poland; 2016;

8. Górski A, Grassmann M, Sarnacka E (editor), Standard wykonywania zawodów medycznych. Warszawa 2019. p. 121-133;

9. Walecki P, Lasoń W. Telemedycyna - wprowadzenie. In: Martyniak J, editor. Podstawy informatyki z elementami telemedycyny Ćwiczenia dla studentów medycyny. Kraków: Wydawnictwo Uniwersytetu Jagiellońskiego; 2005. p. 118.

10. Kubiak R. Prawo medyczne, 3rd edition. Warsaw: C.H. Beck; 2017.

11. Stanisław Z. i Andrzej O. v. State Treasury (2011) III KK 29/11, the Supreme Court, 7 October.

12. Act of 6 November 2008 on Patients' Rights and the Patient's Rights Ombudsman. Journal of Laws of 2017, item 1318, 4 July(consolidated text: Journal of Laws of 2019, item 1127, PL: t.j.Dz.U. 2019 poz. 1127).

13. the Constitutional Court's judgment of 5 March 2013, Act 2/11, OTK-A 2013, no. 3, item 24, Journal of Laws, item 375.

14. Karkowska D (editor). Ustawa o prawach pacjenta i Rzeczniku Praw Pacjenta. Komentarz.Warsaw: Wolters Kluwer Poland; 2016.

15. Act of 25 June 1999 on cash benefits from social insurance in case of illness and maternity. Journal of Laws of 2017, item 1368, 12 July. (consolidated text: Journal of Laws of 2019, item 645, PL: t.j.Dz.U. 2019 poz. 645).

16. Act of 19 August 1994 on Mental Health Protection. Journal of Laws of 2017, item 882, 5 May. (consolidated text: Journal of Laws of 2018, item 1878, PL: t.j.Dz.U. 2018 poz. 1878).

17. Act of 28 April 2011 on the Information System in Health Care. Journal of Laws of 2017, item 1845, 5 October. (consolidated text: Journal of Laws of 2019, item 408, PL: t.j.Dz.U. 2019 poz. 408).

18. Wąsik D. Ustawa o systemie informacji w ochronie zdrowia. Komentarz. Warsaw: Lex; 2015.

19. M. Sp. z o.o. w Z. v. Minister of Finance (2015) I SA/Kr 721/15, Voivodeship Administrative Court in Krakow, 23 June.

20. Act of 15 July 2011 on the professions of a nurse and a midwife. Journal of Laws of 2016, item 1251, 16 August. (consolidated text: Journal of Laws of 2019, item 576, PL: t.j. Dz.U. 2019 poz. 576).

21. Lis W, Sadowska M (editor). Ustawa o zawodach pielęgniarki i położnej. Komentarz. Warsaw: Wolters Kluwer Poland; 2019.

22. American Hospital Association. Trendwatch, The Promise of Telehealth For Hospitals, Health Systems and Their Communities. Washington; 2015.

23. Drew H, Vass M. Overcoming the hurdles to the adoption of telemedicine [Internet]. 2016 [cited 2017 Nov 22]. Available from: http://www.osborneclarke.com/insights/overcoming-the-hurdles-tothe-adoption-of-telemedicine/

24. PwC Health Research Institute. Medical Cost Trend 2016 [Internet]. 2016 [cited 2017 Nov 27]. Available from: https://www.achp.org/wpcontent/uploads/pwc-hri-medical-cost-trend-2016.pdf

25. Market study on telemedecine 2018, KomisjaEuropejska, s.32.

26. Debnath D. Activity analysis of telemedicine in the UK. Postgrad Med J 2004; 80:335-338.

27. Asadi H, Akhlaghi H. Ethical and legal aspects of telemedicine and telecare. BMJ Clin Res. 2002; 324(7345).

28. Industry Report on Telemedicine Legal and Regulatory Framework. United4Health 2015, s. 20.
29. Top Markets Report Health IT, Country Case Study, GERMANY, Department of Commerce, USA, 2016.

30. (Model) Professional Code for Physicians in Germany-MBO-Ä 1997. The Resolutions of the114th German Medical Assembly, Kiel 2011.

31. Zanaboni P, Wooton R. Adoption of routine telemedicine in Norwegian hospitals: progress over 5 years. BMC Health Services Res. 16(1).

32. Hartvigsen G, Pedersen S. Lessons learned from 25 years with telemedicine in Northern Norway, 2015 Tromso.

33. Knarvik U, Zanaboni P, Wooton R. Adoption of Routine Telemedicine in Norway: An overview of activities from 2009 to 2011, 2014 Tromso.

34. Grol R, Giesen P, van Uden C. After-hours care in the United Kingdom, Denmark, and the Netherlands: new models. Health affairs. 2006; 25(6): 1733-1737.

35. Giesen P, van Charante EM, Mokkink H, Bindels P, van den Bosch W, \&Grol R. Patients evaluate accessibility and nurse telephone consultations in out-of-hours GP care: determinants of a negative evaluation. Patient education and counseling. 2007; 65(1): 131-136.

36. Van Uden CJT, Ament AJHA, Hobma SO, Zwietering PJ, Crebolder HFJM. Patient satisfaction with out-of-hours primary care in the Netherlands. BMC health services research. 2005; 5(1): 6.

37. Giesen PHJ, Haandrikman LGR, Broens S, Schreuder JLM, Mokkink HGA. GP cooperatives: Does it benefit the GP? [Centrale huisartsenposten: wordt de huisartserbeter van?] Huisarts Wet. 2000; 43: 508-510.

38. van Uden CJT. Studies on general practice out-of-hours care (Doctoral dissertation, Maastricht University). 2005 [cited 2019 May 29]. Available from: https://cris.maastrichtuniversity.nl/portal/files/684243/guid73b004ca-c061-42a3-99cf-f91bb7cd676f-ASSET2.0

39. Patient Federations of Netherlands [cited 2019 May 29]. Available from: https://www.patientenfederatie.nl/themas/spoedzorg/

40. Alpay LL, Henkemans OB, Otten W, Rövekamp TA \& Dumay AC. E-health applications and services for patient empowerment: directions for best practices in The Netherlands. Telemedicine and e-Health. 2010; 16(7): 787-791.

41. Petersson J. Medicine at a distance in Sweden: Spatiotemporal matters in accomplishing working telemedicine. Sci Stud (St Bonaventure) [Internet]. 2011; 24(2): 43-63. Available from: http://www.scopus.com/ inward/record.url?eid=2-s2.0-84861646570\&partnerID=40\&md5=ee 6d9b322a322e8ad85blfb689215013

42. Blix M, Jeansson J. Telemedicine and the Welfare State: The Swedish Experience. Work Pap Ser [Internet]. 2018;(1238). Available from: https://ideas.repec.org/p/hhs/iuiwop/1238.html

43. Blomdahl S, Calissendorff B, Jacobsson U. Patient-Focused Urban TeleOphthalmology Services. J Telemed Telecare [Internet]. 2002 Jan [cited 2019 May 10]; 8(2_suppl): 43-4. Available from: http://www.ncbi.nlm. nih.gov/pubmed/12217130

44. Spri. UtvarderingavTelemedicinskaKonsultationerinomKardiologi. Stockholm; 1999.

45. Carle L, Hellström C, Made S. 'Telemedicini Glesbygdger Nöjda Patienteroch Högre Kompetens'. Lakartidningen. 2001; 98(38): 40.

46. Pettersson H, Holmer NG. Teleradiology in southern Sweden--a tool for reorganization of health care and for education. Comput Methods Programs Biomed [Internet]. [cited 2019 May 13]; 57(1-2): 13-9. Available from: http://www.ncbi.nlm.nih.gov/pubmed/9803993

47. Mohr NM, Young T, Harland KK, Skow B, Wittrock A, Bell A, et al. Emergency Department Telemedicine Shortens Rural TimeTo-Provider and Emergency Department Transfer Times. Telemed e-Health [Internet]. 2018 Aug [cited 2019 May 13]; 24(8): 582-93. Available from: http://www.ncbi.nlm.nih.gov/pubmed/29293413

48. Andersson O, Sjögren J, Åsberg H. Nätläkarbolagendränerarenunder finansieradprimärvård [Telemedicine doctors drain resources from an underfunded primary care]. Dagens Nyheter, March 2. 2017.

49. Ahlzén R, Berggren L, Metsini A, Olsson L, Tegelberg Å. Vetenskapligtstödsaknasfördigitaladiagnoser [Scientific evidence missing for diagnosis with video call] [Internet]. DagensNyheter. 2018. Available from: https://www.dn.se/debatt/vetenskapligt-stodsaknasfor-\%0Adigitala-diagnoser

50. Perspektywy rozwoju polskiej branży ICT do roku 2025., Polska Agencja Rozwoju Przedsiębiorczości, Warszawa; 2017.

51. Ludność. Stan i struktura w przekroju terytorialnym. Główny Urząd Statystyczny, Warszawa; 2017.

52. Społeczeństwo informacyjne w Polsce w 2018r. Główny Urząd Statystyczny, Warszawa; 2018. 